\title{
PENGARUH PEMBELAJARAN BERBASIS BUDAYA LOKAL DAN NILAI KEBHINNEKAAN TERHADAP HASIL BELAJAR SISWA PELAJARAN IPS DI SD NEGERI 067774 KECAMATAN MEDAN JOHOR
}

\author{
Tina Sheba Cornelia ${ }^{1)}$, Juwita Tindaon ${ }^{2)}$ \\ ${ }^{122)}$ Pendidikan Guru Sekolah Dasar Universitas Quality \\ Email : domtinasitompul@gmail.com
}

\begin{abstract}
ABSTRAK
Penelitian ini bertujuan untuk mengetahui: 1) Perbedaan antara hasil belajar IPS siswa yang diajar dengan pendekatan pembelajaran berbasis budaya lokal dengan hasil belajar IPS siswa yang diajar dengan pendekatan konvensional; 2) Perbedaan hasil belajar IPS siswa yang memiliki nilai kebhinnekaan tinggi dibandingkan dengan hasil belajar IPS siswa yang memiliki nilai kebhinekaan rendah; dan 3) Interaksi antara pendekatan pembelajaran dan nilai kebhinekaan terhadap hasil belajar IPS siswa. Penelitian ini dilaksanakan di SD Negeri 067774 Kecamatan Medan Johor. Populasi dalam penelitian ini adalah siswa kelas $\mathrm{V}$ yang terdiri dari 50 siswa. Teknik pengumpulan data dalam penelitian ini yaitu angket nilai kebhinnekaan dan tes hasil belajar IPS. Metode yang digunakan yaitu quasi eksperimen dengan desain faktorial 2x2. Teknik analisis data menggunakan ANAVA dua arah pada taraf signifikan $\alpha=0,05$. Hasil penelitian menunjukkan bahwa: (1) Terdapat perbedaan antara hasil belajar siswa yang diajar dengan pendekatan pembelajaran berbasis budaya lokal dengan hasil belajar IPS siswa yang diajar dengan pendekatan konvensional $\left(F_{\text {hitung }}=17,064\right.$; sig. $\left.=0,000<0,05\right)$; $(2)$ Terdapat perbedaan hasil belajar IPS siswa yang memiliki nilai kebhinnekaan tinggi dibandingkan dengan hasil belajar IPS siswa yang memiliki nilai kebhinekaan rendah $\left(F_{\text {hitung }}=10,602\right.$; sig. $=0,002<$ 0,05); dan (3) Terdapat interaksi antara pendekatan pembelajaran dan nilai kebhinekaan dalam mempengaruhi hasil belajar IPS ( $F_{\text {hitung }}=22,115$; sig. $=0,000<0,05$ ). Hasil penelitian ini menunjukkan bahwa pendekatan pembelajaran dan nilai kebhinekaan berpengaruh terhadap hasil belajar IPS siswa.
\end{abstract}

\section{Kata kunci: Pembelajaran berbasis budaya lokal; Nilai Kebhinnekaan; Hasil belajar IPS}

\begin{abstract}
This study aims to find out: 1) The difference between students 'social studies learning outcomes taught by local cultural-based learning approaches and students' social learning outcomes taught by conventional approaches; 2) Differences in social studies learning outcomes of students who have high diversity values compared to social studies learning outcomes of students who have low diversity values; and 3) Interaction between learning approaches and diversity values towards students' social studies learning outcomes. This research was conducted at 067774 Public Elementary School, Medan Johor District. The population in this study was fifth grade students consisting of 50 students. Data collection techniques in this study were the diversity of questionnaires and social studies learning achievement tests. The method used is quasi experiment with $2 \times 2$ factorial design. Data analysis techniques using two-way ANAVA at a significant level $\alpha=0.05$. The results showed that: (1) There was a difference between the learning outcomes of students who were taught with the approach to learning based on local culture and the learning outcomes of students who were taught with conventional approaches (Fcount $=17.064$; sig. $=0,000<0.05)$; (2) There are differences in social studies learning outcomes of students who have high diversity values compared with social studies learning outcomes of students who have low diversity values (Fcount $=10.602$; sig. $=0.002<0.05$ ); and (3) There is an interaction between learning approaches and diversity values in influencing social studies learning outcomes (Fcount $=22.115$; sig. $=0.000<0.05)$. The results of this study indicate that the learning approach and diversity values influence the students' social studies learning outcomes.
\end{abstract}

Keywords: Local culture based learning; Diversity Value; Social studies learning outcomes 


\section{PENDAHULUAN}

Pembelajaran merupakan bagian yang sangat penting dari suatu pendidikan. Dewasa ini pelaksanaan pembelajaran disekolah pada kenyataannya terjadi cenderung bersifat konvensional, pembelajaran yang terjadi masih didominasi oleh aktivitas guru (Ahmad, dkk, 2017). Tidak banyak guru yang kreatif menciptakan pola pembelajaran yang menarik bagi siswa padahal pemerintah selama ini telah berupaya meningkatkan kompetensi guru dalam bidang ini. Jika hal ini terus dibiarkan maka akan berdampak pada hasil belajar siswa sehingga dalam jangka panjang akan menyebabkan menurunnya kualitas pendidikan di suatu negara. Sebuah peradaban akan menurun jika terjadi demoralisasi pada masyarakatnya selain itu kualitas pendidikan juga merupakan faktor penentu kemajuan suatu peradaban di suatu daerah. Indonesia saat ini sedang menghadapi krisis multidimensi yang berkepanjangan yang berpengaruh pada segala aspek kehidupan termasuk krisis dalam bidang karakter serta penanaman nilai-nilai luhur dalam kehidupan sehari-hari. Megawangi (2004:3) mengatakan bahwa ketika negara negara lain (Thailand, Malaysia, Korea Selatan, dan lain-lain) telah bangkit dengan segera setelah mengalami krisis moneter yang melanda Asia pada tahun 1997 Indonesia sampai kini masih kelihatan suram untuk bangkit dari keterpurukan ekonomi.

Putra (2017) menyebutkan bahwa arus globalisasi telah melahirkan nilai-nilai baru, gaya hidup baru dan pola interaksi sosial baru dengan segala akibatnya antara lain tajamnya kesenjangan sosial, rusaknya keharmonisan antar sesama dengan maraknya konflik antar etnis, perubahan nilai dan fungsi keluarga, individualisme dan rasa tidak peduli terhadap sesama, tipisnya rasa solidaritas dan kebersamaan, hilangnya rasa cinta produk dalam negeri, menipisnya rasa cinta dan penghargaan terhadap nilai-nilai budaya lokal. Hal tersebut didukung oleh hasil kajian Mubah (2011) dan Suneki (2012) yang menunjukkan bahwa pesatnya perkembangan zaman dapat menimbulkan berbagai permasalahan salah satunya yaitu bidang kebudayaan. Senada dengan itu Yusrizal (2017) mengatakan perkembangan globalisasi akan menghadapkan anak pada banyaknya pilihan tentang nilai baik itu nilai yang baik untuk dicontoh begitu juga sebaliknya. Nilai-nilai yang dianggap baik oleh suatu kelompok masyarakat bukan suatu hal yang tak mungkin akan luntur dan digantikan oleh nilai-nilai baru yang belum tentu sesuai dengan budaya masyarakat. Selain itu kearifan lokal dapat berfungsi sebagai salah satu nilai-nilai yang luhur. Dengan kata lain kearifan lokal dapat menjadi sumur yang tidak kunjung kering walaupun pada musim kemarau, nilai-nilai kebijaksanaan pagi perwujudan cita-cita yang seimbang, baik secara lahiriah maupun batiniah (Yusrizal, 2017).

Pembelajaran berbasis budaya lokal adalah suatu pendekatan pembelajaran kontekstual yang mempelajari isu-isu budaya yang ada dilingkungan sekitar tempat tinggal. Selain nilai kebudayaan lokal, nilai-nilai kebhinekaan juga perlu ditanamkan pada siswa sejak dini. Sebab nilai kebhinekaan merupakan nilai yang dapat dijadikan sebagai pedoman untuk menentukan perilaku yang baik atau tidak baik dalam kehidupan masyarakat. Amuk (2016) menyebutkan ada beberapa nilai kebhinnekaan yang harus ditanamkan kepada siswa sejak dini diantaranya yaitu: 1) Nilai toleransi merupakan sikap untuk mengakui dan menghormati hak-hak asasi dalam hidup bermasyarakat; 2) Nilai kesetaraan merupakan sikap yang menekankan pada kesederajatan dan kesetaraan terhadap budaya suku lainnya; 3) nilai demokrasi merupakan sikap yang mengakui bahwa setiap orang memiliki hak dan kewajiban yang sama, serta mengakui kebhinekaan sebagai hal yang wajar; dan 4) keadilan merupakan tindakan yang memberikan hak yang sama pada orang yang memiliki status sama.

Arus globalisasi dapat mengancam eksistensi budaya Indonesia, misalnya seperti hilangnya budaya silaturrahmi, menurunnya rasa nasionalisme serta pudarnya sifat kekeluargaan dan kepercayaan diri sebagai bangsa. Senada dengan itu, Syam (2015) melalui hasil penelitiannya mengungkapkan bahwa media di era global dapat berdampak pada perubahan nilai-nilai budaya di kalangan remaja yaitu sebanyak $46 \%$ remaja menyatakan bahwa budaya luar telah membuat perubahan pada diri mereka. Oleh karena itu tujuan penelitian ini adalah untuk melihat pengaruh pembelajaran berbasis budaya lokal 
Sumatera Utara dan nilai kebhinekaan terhadap hasil belajar siswa di Kota Medan.

\section{METODE PENELITIAN}

Penelitian ini menggunakan metode quasi eksperimen dengan membandingkan antara pendekatan pembelajaran berbasis budaya lokal dengan pendekatan pembelajaran konvensional. Selain itu itu penelitian ini juga akan melihat perbedaan hasil belajar IPS siswa yang memiliki nilai kebhinnekaan tinggi dengan hasil belajar IPS siswa yang nilai kebhinnekaan rendah. Populasi dalam penelitian ini adalah seluruh kelas $\mathrm{V}$ masingmasing kelas V/a berjumlah 25 siswa dan V/b berjumlah 25 siswa. Kedua kelas tersebut sekaligus dijadikan sampel dalam penelitian ini dengan ketentuan satu kelas menerapkan pendekatan pembelajaran berbasis budaya lokal dan satu kelas lainnya menerapkan pendekatan pembelajaran konvensional. Teknik pengumpulan data yaitu dengan angket nilai kebhinnekaan dan tes pilihan ganda. Sebelum instrument tes digunakan dalam penelitian, sebelumnya dilakukan uji validitas, realibitas, tingkat kesukaran, dan daya beda.

Sebelum hipotesis diuji, maka dilakukan terlebih dahulu uji persyaratan. Uji persyaratan analisis data yang dibutuhkan untuk menguji hipotesis yaitu uji normalitas dan uji homogenitas. Uji normalitas dilakukan dengan Shapiro-Wilk dan uji homogenitas dilakukan dengan uji Levene Test (Ary dkk., 2004). Selanjutnya pengujian hipotesis menggunakan ANAVA dua arah dengan rancangan faktorial $2 \times 2$ dan dengan bantuan SPSS versi 23.

\section{HASIL DAN PEMBAHASAN}

1. Distribusi Frekuensi

a) Hasil Belajar IPS Siswa yang Diajar dengan Pendekatan Pembelajaran Berbasis Budaya Lokal dan Memiliki Nilai Kebhinnekaan Tinggi

Dari perhitungan statistik diketahui bahwa hasil belajar IPS siswa yang diajar dengan pendekatan pembelajaran berbasis budaya lokal dan memiliki nilai kebhinnekaan tinggi mendapatkan skor terendah yaitu 70 , dan skor tertinggi yaitu 90, dengan rata-rata sebesar 79,79 varian sebesar 45,87 dan standar deviasi sebesar 6,77. Distribusi frekuensi hasil belajar IPS siswa disajikan dalam histogram berikut ini.

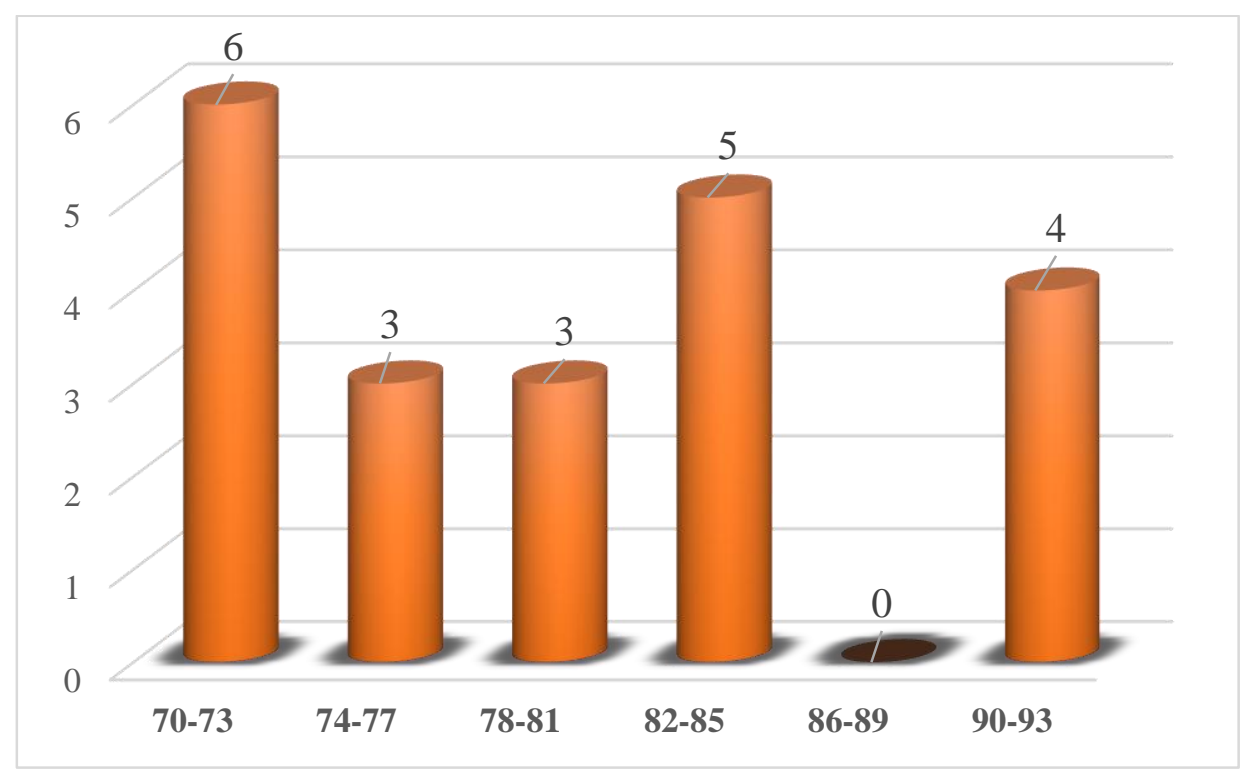

Gambar 1 Hasil Belajar IPS Siswa yang Diajar dengan Pendekatan Pembelajaran Berbasis Budaya Lokal dan Memiliki Nilai Kebhinnekaan Tinggi

b) Hasil Belajar IPS Siswa yang Diajar dengan Pendekatan Pembelajaran Berbasis Budaya Lokal dan Memiliki Nilai Kebhinnekaan Rendah

Dari perhitungan statistik diketahui bahwa hasil belajar IPS siswa yang diajar dengan 
pendekatan pembelajaran berbasis budaya lokal dan memiliki nilai kebhinnekaan rendah mendapatkan skor terendah yaitu 57, dan skor tertinggi yaitu 90, dengan rata-rata sebesar 74,44 varian sebesar 108,33 dan standar deviasi sebesar 10,41. Distribusi frekuensi hasil belajar IPS siswa disajikan dalam histogram berikut ini.

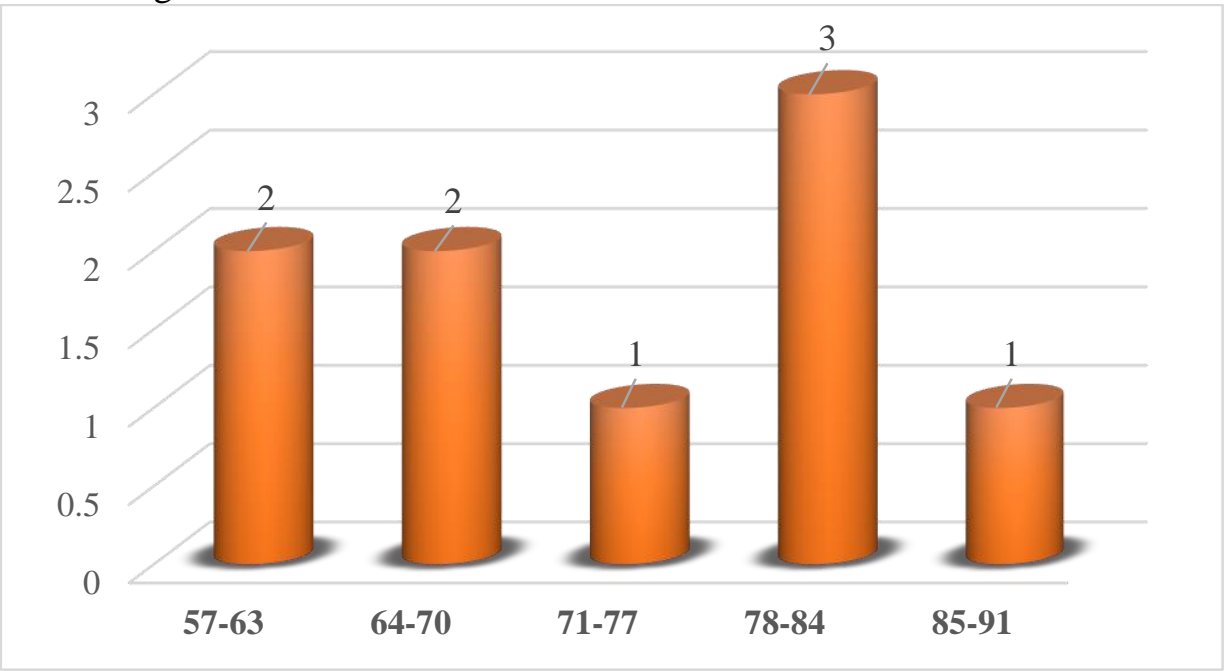

Gambar 2 Hasil Belajar IPS Siswa yang Diajar dengan Pendekatan Pembelajaran Berbasis Budaya Lokal dan Memiliki Nilai Kebhinnekaan Rendah

c) Hasil Belajar IPS Siswa yang Diajar dengan Pendekatan Konvensional dan Memiliki Nilai Kebhinnekaan Tinggi

Dari perhitungan statistik diketahui bahwa hasil belajar IPS siswa yang diajar dengan pendekatan konvensional dan memiliki nilai kebhinnekaan tinggi mendapatkan skor terendah yaitu 57 , dan skor tertinggi yaitu 83 , dengan rata-rata sebesar 72,59 varian sebesar 57,99 dan standar deviasi sebesar 7,62. Distribusi frekuensi hasil belajar IPS siswa disajikan dalam histogram berikut ini.

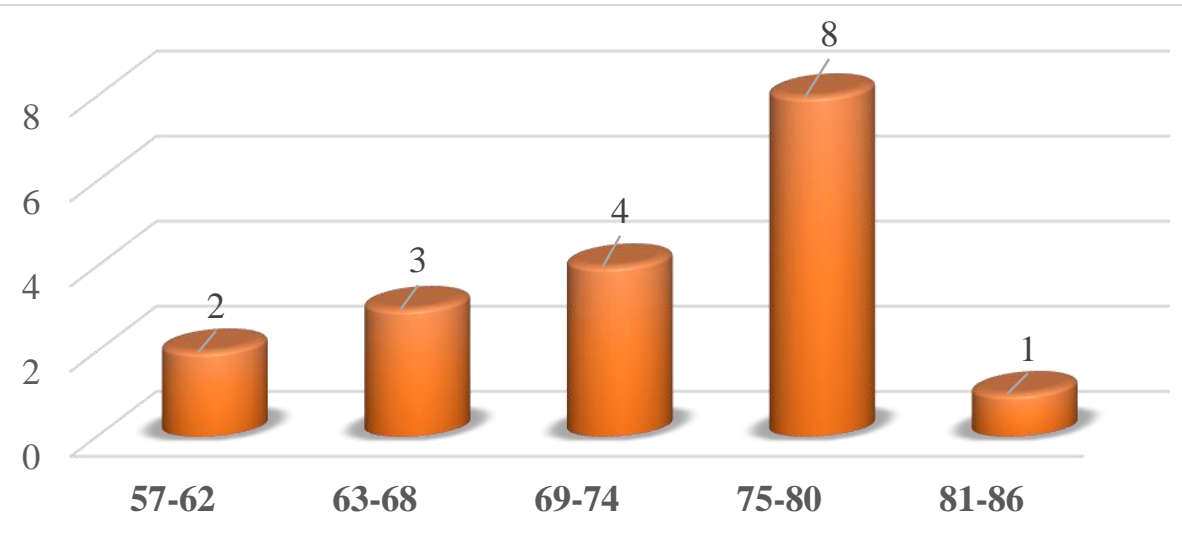

Gambar 3 Hasil Belajar IPS Siswa yang Diajar dengan Pendekatan Konvensional dan Memiliki Nilai Kebhinnekaan Tinggi

d) Hasil Belajar IPS Siswa yang Diajar dengan Pendekatan Konvensional dan Memiliki Nilai Kebhinnekaan Rendah

Dari perhitungan statistik diketahui bahwa hasil belajar IPS siswa yang diajar dengan pendekatan konvensional dan memiliki nilai kebhinnekaan rendah mendapatkan skor terendah yaitu 57, dan skor tertinggi yaitu 73 , dengan rata-rata sebesar 64,72 varian sebesar 33,25 dan standar deviasi sebesar 5,77. Distribusi frekuensi hasil belajar IPS siswa disajikan dalam histogram berikut ini. 


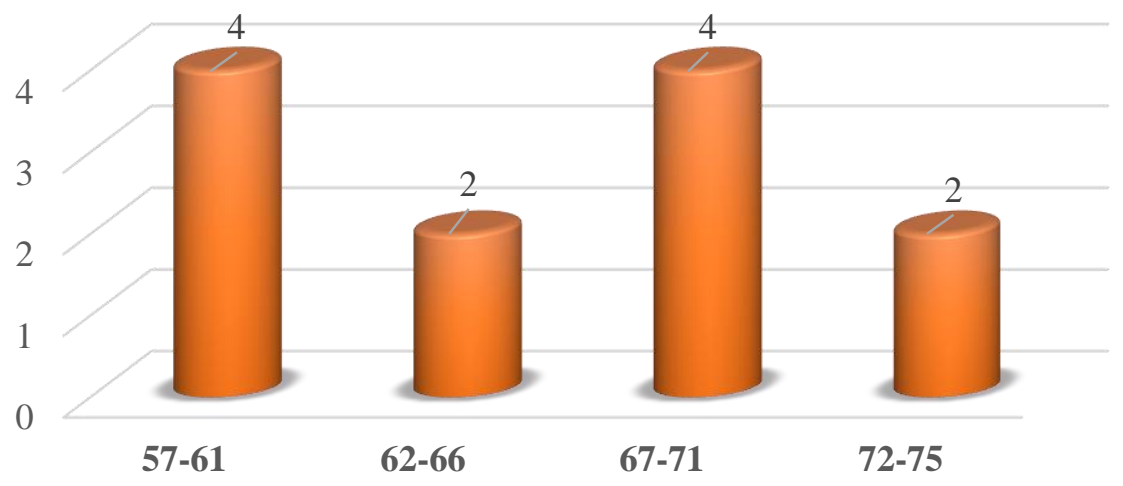

Gambar 4 Hasil Belajar IPS Siswa yang Diajar dengan Pendekatan Konvensional dan Memiliki Nilai Kebhinnekaan Rendah

2. Uji Prasyarat

a) Uji Normalitas

Pengujian normalitas data dilakukan dengan uji Kolmogorov-Smirnov

Tabel 1 Hasil Uji Normalitas Data Penelitian menggunakan SPSS 23. Uji normalitas data secara keseluruhan dapat dilihat pada tabel berikut ini:

Tests of Normality

\begin{tabular}{|l|r|r|r|r|r|r|}
\hline & \multicolumn{2}{|c|}{ Kolmogorov-Smirnov } & \multicolumn{3}{c|}{ Shapiro-Wilk } \\
\cline { 2 - 7 } & Statistic & \multicolumn{1}{c|}{ df } & \multicolumn{1}{c|}{ Sig. } & \multicolumn{1}{c|}{ Statistic } & \multicolumn{1}{c|}{ df } & \multicolumn{1}{c|}{ Sig. } \\
\hline $\begin{array}{l}\text { Standardized Residual for } \\
\text { Hasil_Belajar }\end{array}$ &, 105 & 60 &, 097 &, 980 & 60 &, 434 \\
\hline
\end{tabular}

a. Lilliefors Significance Correction

Berdasarkan di atas dapat diketahui bahwa nilai signifikan sebesar 0,097 >0,05, dengan demikian dapat disimpulkan bahwa data penelitian berdistribusi dengan normal.

\section{b) Uji Homogenitas}

Uji homogenitas bertujuan untuk mengetahui sampel penelitian bersifat homogen atau tidak. Ringkasan perhitungan uji homogenitas dapat dilihat pada tabel berikut ini:

Tabel 2 Pengujian Homogenitas Data Penelitian

\section{Levene's Test of Equality of Error Variances ${ }^{a}$}

Dependent Variable: Hasil Belajar

\begin{tabular}{|r|r|r|r|}
\hline F & df1 & df2 & \multicolumn{1}{|c|}{ Sig. } \\
\hline 1,738 & 3 & & 56
\end{tabular}

Tests the null hypothesis that the error variance of the dependent variable is equal across groups.

a. Design: Intercept + Perlakuan + Keterampilan_Sosial + Perlakuan * Keterampilan_Sosial

Berdasarkan di atas dapat diketahui bahwa nilai signifikan sebesar $0,170>0,05$, dengan demikian dapat disimpulkan bahwa kelompok data penelitian relatif sama atau bersifat homogen.

\section{Uji Hipotesis}

Tabel 3 Output SPSS Hasil Perhitungan ANAVA dua arah

Dependent Variable: Hasil Belajar
Tests of Between-Subject

\begin{tabular}{|l|r|r|r|r|r|}
\hline Source & $\begin{array}{c}\text { Type III Sum of } \\
\text { Squares }\end{array}$ & df & \multicolumn{1}{c|}{$\begin{array}{c}\text { Mean } \\
\text { Square }\end{array}$} & \multicolumn{1}{c|}{ F } & \multicolumn{1}{c|}{ Sig. } \\
\hline Corrected Model & $1756,052^{\mathrm{a}}$ & 3 & 585,351 & 10,546 &, 000 \\
Intercept & 285747,784 & 1 & 285747,784 & 5148,142 &, 000
\end{tabular}




\begin{tabular}{|l|r|r|r|r|r|} 
Pendekatan Pembelajaran & 947,162 & 1 & 947,162 & 17,064 &, 000 \\
Nilai Kebhinnekaan & 588,478 & 1 & 588,478 & 10,602 &, 002 \\
Pendekatan Pembelajaran * & 238,095 & 1 & 1194,667 & 22,115 &, 000 \\
Nilai Kebhinnekaan & 3108,282 & 56 & 55,505 & & \\
Error & 331946,000 & 60 & & & \\
Total & 4864,333 & 59 & & & \\
Corrected Total & & & \\
\hline
\end{tabular}

a. R Squared $=, 361$ (Adjusted R Squared $=, 327$ )

\section{- Hipotesis Pertama}

Hipotesis statistik yang diuji adalah:

$$
\text { Ho : } \mu \mathrm{A}_{1}=\mu \mathrm{A}_{2}
$$$$
\mathrm{Ha}: \mu \mathrm{A}_{1} \neq \mu \mathrm{A}_{2}
$$

Berdasarkan output SPSS diperoleh bahwa nilai $F_{\text {hitung }}$ pada pendekatan pembelajaran yaitu 17,064 dan nilai signifikan yaitu 0,000 dengan $\alpha=0,05$. Maka dapat dilihat bahwa nilai signifikan $0,000<0,05$ sehingga pengujian hipotesis menolak $\mathrm{H}_{\mathrm{o}}$ dan menerima $\mathrm{H}_{\mathrm{a}}$. Dengan demikian terdapat perbedaan yang signifikan antara hasil belajar IPS siswa yang yang diajar menggunakan pendekatan pembelajaran berbasis budaya lokal dengan hasil belajar IPS siswa yang diajar dengan pendekatan konvensional.

\section{- Hipotesis Kedua}

Hipotesis statistik yang diuji adalah

$$
\begin{aligned}
& \text { Ho: } \mu B_{1}=\mu B_{2} \\
& \text { Ha }: \mu B_{1} \neq \mu B_{2}
\end{aligned}
$$

Berdasarkan output SPSS diperoleh bahwa nilai $\mathrm{F}_{\text {hitung }}$ pada nilai kebhinnekaan yaitu 10,602 dan nilai signifikan yaitu 0,002 dengan $\alpha=$ 0,05 . Maka dapat dilihat bahwa nilai signifikan $0,0002<0,05$ sehingga pengujian hipotesis menolak $\mathrm{H}_{\mathrm{o}}$ dan menerima $\mathrm{H}_{\mathrm{a}}$. Dengan demikian terdapat perbedaan yang signifikan antara hasil belajar IPS siswa yang memiliki nilai kebhinnekaan tinggi dengan hasil belajar siswa yang memiliki nilai kebhinnekaan rendah.

\section{- Hipotesis Ketiga}

Hipotesis statistik yang diuji adalah

$$
\begin{aligned}
& \text { Ho: } \mathrm{A} \times \mathrm{B}=0 \\
& \mathrm{Ha}: \mathrm{A} \times \mathrm{B} \neq 0
\end{aligned}
$$

Berdasarkan output SPSS diperoleh bahwa $F_{\text {hitung }}=22,115$ dan nilai signifikan sebesar 0,000 dengan $\alpha=0,05$. Maka dapat dilihat bahwa nilai sig. $0,000<0,05$ sehingga pengujian hipotesis menolak $\mathrm{H}_{\mathrm{o}}$ dan menerima $\mathrm{H}_{\mathrm{a}}$. Dengan demikian terdapat interaksi antara pendekatan pembelajaran dan nilai kebhinnekaan dalam mempengaruhi hasil belajar IPS siswa.

Pembelajaran IPS merupakan muatan pembelajaran yang bersifat luas yang mempelajari tentang kehidupan sehari-hari siswa, yang meliputi, keragaman di negeri, berbagai bahasa, berbagai suku, berbagai agama dan lainnya. Penjelasan ini sejalan dengan pernyataan Saputra (2017) dalam penelitiannya yang mengatakan Ilmu Pengetahuan Sosial (IPS) merupakan ilmu pengetahuan yang mengkaji seperangkat, peristiwa, fakta, konsep dan generalisasi yang berkaitan dengan isu sosial. Untuk ketercapaian tujuan pemerintah dalam pendidikan karakter serta melestarikan budaya daerah diharapkan guru lebih kreatif dalam memilih pendekatan pembelajaran yang dapat menghadirkan budaya lokal sebagai materi pembelajaran. Dengan demikian pada generasi muda kedepan senantiasa dapat melestarikan budaya yang telah diwariskan sejak dahulu.

\section{KESIMPULAN}

Berdasarkan pembahasan yang telah diuraikan sebelumnya, maka dapat ditarik beberapa kesimpulan diantaranya sebagai berikut:

1. Terdapat perbedaan antara hasil belajar siswa yang diajar dengan pendekatan pembelajaran berbasis budaya lokal dengan hasil belajar IPS siswa yang diajar dengan pendekatan konvensional $\left(\mathrm{F}_{\text {hitung }}=17,064\right.$; sig. $=$ $0,000<0,05)$

2. Terdapat perbedaan hasil belajar IPS siswa yang memiliki nilai kebhinnekaan tinggi dibandingkan dengan hasil belajar IPS siswa yang memiliki nilai kebhinekaan rendah $\left(F_{\text {hitung }}=10,602\right.$; sig. $\left.=0,002<0,05\right)$

3. Terdapat interaksi antara pendekatan pembelajaran dan nilai kebhinekaan dalam mempengaruhi hasil belajar IPS $\left(F_{\text {hitung }}=22,115 ;\right.$ sig. $\left.=0,000<0,05\right)$ 


\section{DAFTAR PUSTAKA}

Ary, Donald, dkk. 2004. Pengantar Penelitian Dalam Pendidikan. Terjemahan Arief Furchan Surabaya: Usaha Nasional.

M. Amin. 2016. Soft Skills Berbasis Budaya Lokal untuk Pendidikan Calon Guru SMK, Jurnal Kependidikan, pp. 41-55.

N. Jananti and T. Tarmudji. 2014. Pengaruh Kepercayaan Diri, Budaya Lokal dan Pendidikan Agama terhadap Hasil Belajar Mata Pelajaran Ekonomi Siswa Kelas XI IPS SMA Negeri 1 Demak Tahun Ajaran 2013/2014. Economic Education Analysis Journal, vol. 3 No 2.

Pi'i. 2017. Penanaman Nilai-nilai Kebhinekaan Melalui Pembelajaran Sejarah SMA. Sejarah dan Budaya, vol. 2
Suharianta, N. Syahruddin and T. Renda, 2014. Pengaruh Metode Pembelajaran Simulasi Berbasis Budaya Lokal terhadap Hasil Belajar IPS. Jurnal Mimbar PGSD Universitas Pendidikan Ganesha, vol. 2 No 1

W. Amuk, "Pembelajaran Nilai-nilai Multikulturalisme dalam Teks Sastra," 2016. [Online]. Available: https://dyanarsya.wordpress.com. [Accessed 15 April 2019].

Yusrizal, 2017. Pendidikan Karakter Berbasis Kearifan Lokal pada Pelajaran IPS untuk Siswa Sekolah Dasar. in Prosiding Seminar Nasional Tahunan Fakultas Ilmu Sosial Universitas Negeri Medan. Medan. 